\title{
SKETCH-UP
}

\section{The rise and fall of the Great Barrier Reef}

Nat. Geo. https://doi.org/10.1038/s41561-018-0127-3 (2018).

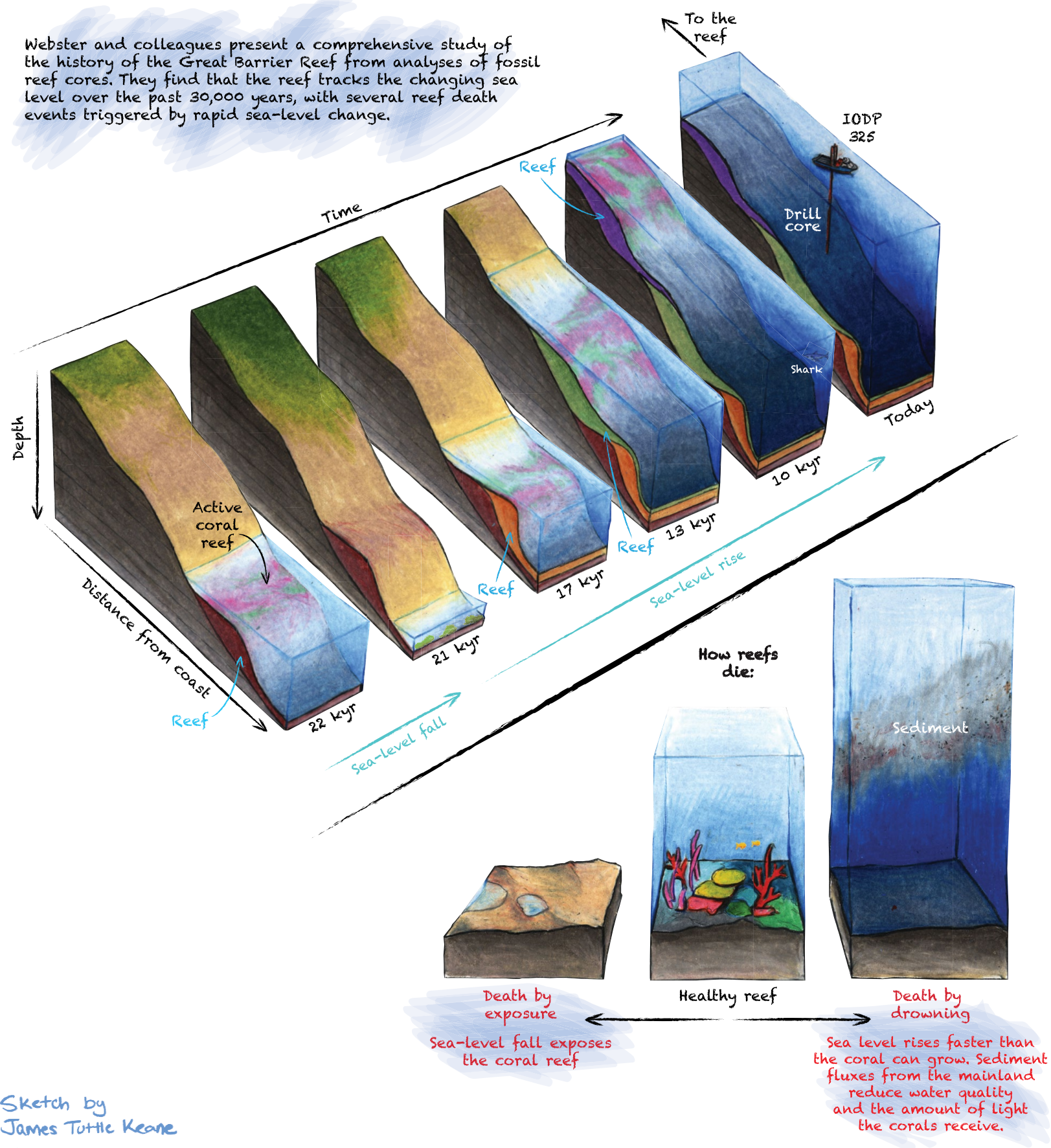

Published online: 28 May 2018

https://doi.org/10.1038/s41561-018-0154-0 